\title{
Relação entre o dia da ovulação e a taxa de prenhez em éguas receptoras de embriões
}

[a] Quirón Reprodução Equina, Cambuquira, MG, Brasil

[b] Universidade Federal de Lavras (UFLA), Lavras, MG, Brasil

[c] Universidade Federal Rural do Rio de Janeiro (UFRRJ), Seropédica, RJ, Brasil

*Autor correspondente

e-mail: rolcachagas@gmail.com

\section{Resumo}

Um dos principais desafios em um programa de transferência de embrião em equinos é a sincronização da égua doadora com a égua receptora, pois a duração do estro em éguas é muito variável e nem sempre terapias hormonais são suficientes para se conseguir essa sincronização. Durante as estações de monta 2015/2016 e 2016/2017, foram acompanhadas 351 receptoras na Central Quirón Reprodução Equina com sede na Fazenda Nossa Senhora Aparecida, município de Cambuquira, no Sul de Minas Gerais. As receptoras eram divididas em lotes e o controle folicular das éguas de cada lote era realizado, em média, três vezes por semana. O dia da ovulação era considerado como D0 e as receptoras eram inovuladas de D4 a D8. Estas eram avaliadas e classificadas de acordo com suas condições uterinas, por exemplo, tônus à palpação e morfoecogenicidade na ultrassonografia, e as selecionadas recebiam os embriões. 0 diagnóstico de gestação era feito aos 14 dias de idade do embrião. As taxas de prenhez, relacionadas ao dia da ovulação da receptora, foram as seguintes: D4, 66,6\%; D5, 75,23\%; D6, 73,87\%; D7, 61,53\%; e D8, 75\%; com média de 70,65\% de prenhezes confirmadas. Foi realizado o teste de comparação múltipla com correção de Bonferroni (p-valor $<0,005$ ) para avaliar a associação entre o dia da ovulação e a taxa de prenhez,e o teste foi não significativo ( $p$-valor $=0,228)$, indicando que não existe diferença na taxa de prenhez em relação ao dia da ovulação. Assim, o presente estudo confirma o resultado de outros trabalhos, que sugerem a utilização de receptoras no intervalo de D4 a D8. Além disso, o resultado demonstra que a classificação e seleção de receptoras com boas condições uterinas foi eficiente, visto que não houve diferença considerável entre os grupos. Isso comprova que o melhor dia para a inovulação é uma característica individual de cada égua, o que reforça a necessidade da avaliação e classificação do útero das receptoras antes da transferência do embrião, e a 
utilização de receptoras que apresentem bom tônus e morfoecogenicidade uterina, que está intimamente relacionado ao nível sérico de progesterona, contribuindo para melhores resultados.

Palavras-chave: Transferência de embrião. Receptora. Ovulação. 